\title{
CHEMICAL AND MINERALOGICAL CHARACTERISTICS OF LATERITIC IRON ORE DEPOSIT AT IYUKU, ETSAKO WEST LOCAL GOVERNMENT AREA OF EDO STATE, NIGERIA
}

\author{
IRABOR E. E. I. AND OKOLO P. O.
}

(Received 22 April 2010; Revision Accepted 8, June 2010)

\begin{abstract}
The lateritic iron ore deposit at lyuku in Etsako West Local Government Area in Edo State, Nigeria was assayed chemically and mineralogically. The results of the chemical assay obtained are $\mathrm{Fe}_{2} \mathrm{O}_{3}(48.20-55.63 \%), \mathrm{Al}_{2} \mathrm{O}_{3}(12.50-$ $18.00 \%), \mathrm{SiO}_{2}(9.48-30.71 \%) \mathrm{CaO}(0.36-0.41 \%), \mathrm{MgO}(2.51-2.60 \%)$ moisture $(1.21-1.77 \%)$ and L.O.I (4.08 $8.35 \%)$. The mineralogical analysis indicates the predominant presence of goethite, haematite and halloysite, whereas, gibbsite and anatase were present as minor species.
\end{abstract}

KEY WORDS: laterites, goethite, haematite, halloysite, gibbsite and anatase.

\section{INTRODUCTION}

Laterite is the residual weathering products of rocks which contain oxides and hydroxides of iron and aluminium, Ludman et al (1982). The occurrence of laterites in sols of tropics and subtropics where there is high rainfall, intense leaching and oxidizing warm environment is well established Allen (1995). The formation of laterites arising from the oxidation and intense hydrolysis and leaching of minerals from feldspars and the ferromagnesium minerals is well known, Levin (1981). The wide variation in the colour of laterites due to the differences in the content of the iron minerals have been reported Onyeobi et al (1994). The occurrence of large deposits of laterites in Nigeria has been reported (Emofurieta et al (1995). The occurrence of important iron and aluminium minerals such as haematite $\left(\mathrm{Fe}_{2} \mathrm{O}_{3}\right)$ and gibbsite $\left(\mathrm{Al}_{2} \mathrm{O}_{3} \cdot 3 \mathrm{H}_{2} \mathrm{O}\right)$ as constitutents of laterites have been variously reported, Iwu (1973) and Meketta et al (1977). The current study of the laterite deposit at lyuku, in Edo State, Nigeria, therefore, is to assess the chemical and mineralogical composition.

\section{MATERIALS AND METHODS}

\subsection{SAMPLING}

The samples were collected on profile basis in each site. The profiles were determined by colour variation, fault lines of cleavage and depth as described by Onyeobi et al (1994). A minimum of fifteen (15) samples were collected per depth. The samples in each profile were obtained by the use of geological hammer and spade and were packaged in polythene bags and transported to the laboratory.

2.4 SAMPLE TREATMENTThe samples were airdried in the laboratory.

\subsection{SAMPLE PREPARATION}

The samples collected were kept in the laboratory and allowed to be air-dried. The samples were crushed by use of geological hammer and a laboratory sized jaw crusher. Grinding was carried out by use of two-roll mill and final grinding was carried out using laboratory mortar and pistle. The finely ground samples were stored in labelled containers.

\section{i) Moisture Content}

The samples $(5 \mathrm{~g})$ were weighed in an analytical balance, in $100 \mathrm{ml}$ beakers heated at between $105-110^{\circ} \mathrm{C}$ in a Merment thermostated oven until constant weight were attained. The samples were kept in desiccators, cooled, and weighed again to obtain the weight loss which was calculated as percentage of moisture content. A minimum of three replicate determinations were carried out for each sample.

\section{ii. Loss on Ignition (L.O.1)}

This represents the total amount of volatile materials present in the samples. In order to determine the loss on ignition, the samples $(5 \mathrm{~g})$ were weighed in an analytical balance in porcelain crucible, heated at between $400^{\circ} \mathrm{C}$ for four hours until constant weight were obtained. The samples were thereafter, cooled in the dessicator, weighed and the loss in weight was calculated as percentage of volatile matter present. A minimum of three replicate determinations were carried out for each sample.

iii. Atomic Absorption Spectrophotometer Determination

Chemical Assay

This involved the determination of the chemical make-up of the sample using Atomic Absorption Spectrophotometer. (Bulk Scientific 200A) as described by (Young R.S., 1977).

The determinations were carried out on dry samples which were obtained by taking some quantity of the test sample, heated at $105-110^{\circ} \mathrm{C}$ for one hour to remove moisture, cooled in a dessicator and thereafter kept in a sealed container. The test sample $(1.0 \mathrm{~g})$ was weighed into a beaker, sufficient quantity of Aqua-regia ((3:1) $\mathrm{HCl}$ :

Irabor E. E. I. Department of Chemistry, University of Benin, Benin City, Nigeria

Okolo P. O. Department of Chemistry, University of Benin, Benin City, Nigeria 
$\mathrm{HNO}_{3}$ was added into the beaker and the mixture was heated to near dryness. $50 \% \mathrm{H}_{2} \mathrm{SO}_{4}(10 \mathrm{ml})$ was added and heated until the fumes of $\mathrm{SO}_{2}$ were observed. Deionised water was added and the solution stirred, and filtered. The filtrate $(A)$ was kept. The solid residue $\left(r_{1}\right)$ was fused with $\mathrm{Na}$ at $1200^{\circ} \mathrm{C}$ in a muffle furnace. Thereafter, $\mathrm{HCl}(1.5 \mathrm{M})$ was added, warmed and the filtrate $(B)$ was added to the initial filtrate $(A)$. The residue $\left(r_{2}\right)$ was kept for silica determination.

The combined filtrate $(A+B)$ was heated to boiling, solid $\mathrm{NH}_{4} \mathrm{Cl}$ was added, two drops of methyl red indicator was added and conc. aqueous ammonia solution was added dropwise until all the ammonium hydroxide elements was precipitated $\left(P_{1}\right)$ and filtered. The filtrate $(C)$ from the above was kept for alkalineearth metal determination.

The precipitate $\left(P_{1}\right)$ from the above was dissolved in $\mathrm{HCl}(1.5 \mathrm{M})$, warmed and reprecipitated $\left(P_{2}\right)$ to remove any occluded alkaline earth metal. The filtrate (D)) was added to the previous filtrate (C). The filtrate (D + C) was transferred into a $250 \mathrm{ml}$ volumetric flask, and de-ionised water was added to make up to the mark. Aliquot of this was taken for $\mathrm{Ca}, \mathrm{Mg}, \mathrm{Ni}, \mathrm{Mn}$ and Cr...... determinations.

The precipitate from above $\left(\mathrm{P}_{2}\right)$ was dissolved in warm $\mathrm{HCl}(1.5 \mathrm{~N})$, filtered and transferred to a $25 \mathrm{Gm}$ volumetric flask and de-ionised water was added to make up to the mark (Solution $X$ ). Aliquot of solution $X$ was taken for the determination of Fe, Al, Ti, P.V. Replicate preparations were made.
For the Atomic Absorption Spectrophotometer determination of aluminum and titanium, nitrous oxide - air flame was used whereas the air-acetylene flame was used for the determination of the other elements. The amount of each element present was expressed as percentage of the oxide of the metal.

\section{SILICA DETERMINATION}

The total silica was determined using the standard method (ASTM, 1965). The residue from the acid digestion of the samples, was taken into a platinum crucible, ministered with concentrated sulphuric acid and evaporated to dryness. This was taken into a muffle furnace, heated at temperature of $1200^{\circ} \mathrm{C}$ for 20 minutes, cooled in a dessicator and weighed. Thereafter 2 drops of $\mathrm{H}_{2} \mathrm{SO}_{4}$ (1:1) was added followed by addition of hydrofluoric acid $(10 \mathrm{ml})$, and the content was evaporated to dryness on a hot plate. This was taken back to the muffle furnace and ignited at $1200^{\circ} \mathrm{C}$ for 20 minutes, cooled and reweighed. The difference in weight represents the total silica present. Replicate determinations were carried out.

\section{MINERALOGICAL ANALYSIS}

The samples were pulverized to fine particles $(\leq$ $2 \mu \mathrm{m})$ and were subjected to X-ray diffraction using Phillips X-ray Diffractometer PW 1800 with $\mathrm{Cu}, \mathrm{K} \alpha$ radiation source. The generator operating conditions were $40 \mathrm{KV}$ and $5 \mathrm{SmA}$. The Diffractograms obtained were compared with the standard X-ray powder diffraction file published by the Joint Committee on the Power Diffraction Standards (JCPDS) for the identification of the different mineral species.

\section{RESULTS AND DISCUSSIONS}

TABLE 1: RESULT OF THE CHEMICAL ASSAY OF LATERITE IN IYUKU

\begin{tabular}{|l|l|l|l|l|l|}
\hline DEPTH (M) & $\begin{array}{l}\text { IYUKU 1 } \\
\text { 0-1.0 }\end{array}$ & $\begin{array}{l}\text { IYUKU 2 } \\
\mathbf{1 . 0 - 2 . 5}\end{array}$ & $\begin{array}{l}\text { IYUKU 3 } \\
\mathbf{2 . 5 - 3 . 2}\end{array}$ & MEAN & STANDARD DEVIATION \\
\hline Moisture (\%) & 1.77 & 2.13 & 1.21 & 1.70 & 0.46 \\
\hline L.O.I (\%) & 8.35 & 8.04 & 4.08 & 6.82 & 2.38 \\
\hline $\mathrm{Fe}_{2} \mathrm{O}_{3}(\%)$ & 59.00 & 59.70 & 48.20 & 55.63 & 6.45 \\
\hline $\mathrm{Al}_{2} \mathrm{O}_{3}(\%)$ & 18.00 & 15.25 & 12.50 & 15.25 & 2.75 \\
\hline $\mathrm{CaO}^{(\%)}$ & 0.38 & 0.41 & 0.36 & 0.38 & 0.03 \\
\hline $\mathrm{MgO}(\%)$ & 2.60 & 2.51 & 2.60 & 2.57 & 0.05 \\
\hline $\mathrm{Cr}_{2} \mathrm{O}_{3}(\%)$ & 0.02 & 0.01 & 0.03 & 0.02 & 0.01 \\
\hline $\mathrm{V}_{2} \mathrm{O}_{5}(\%)$ & 0.01 & 0.01 & $\mathrm{~N} . \mathrm{D}$ & 0.01 & 0.00 \\
\hline $\mathrm{MnO}_{2}(\%)$ & 0.16 & 0.10 & 0.06 & 0.11 & 0.05 \\
\hline $\mathrm{Ni}_{2} \mathrm{O}(\%)$ & 0.02 & 0.01 & 0.05 & 0.03 & 0.02 \\
\hline $\mathrm{P}_{2} \mathrm{O}_{5}(\%)$ & 0.01 & $\mathrm{~N} . \mathrm{D}$ & $\mathrm{N} . \mathrm{D}$ & 0.01 & 0.00 \\
\hline
\end{tabular}




\begin{tabular}{|c|c|c|c|c|c|}
\hline $\mathrm{SiO}_{2}(\%)$ & 9.48 & 11.66 & 30.71 & 17.28 & 11.68 \\
\hline $\mathrm{TiO}_{2}(\%)$ & 0.02 & 0.02 & 0.01 & 0.02 & 0.01 \\
\hline$\frac{\mathrm{SiO}_{2}}{\mathrm{Al}_{2} \mathrm{O}_{3}+\mathrm{Fe}_{2} \mathrm{O}_{3}}$ & 0.29 & 0.37 & 1.21 & 0.62 & \\
\hline
\end{tabular}

N.D $=$ Not Detected

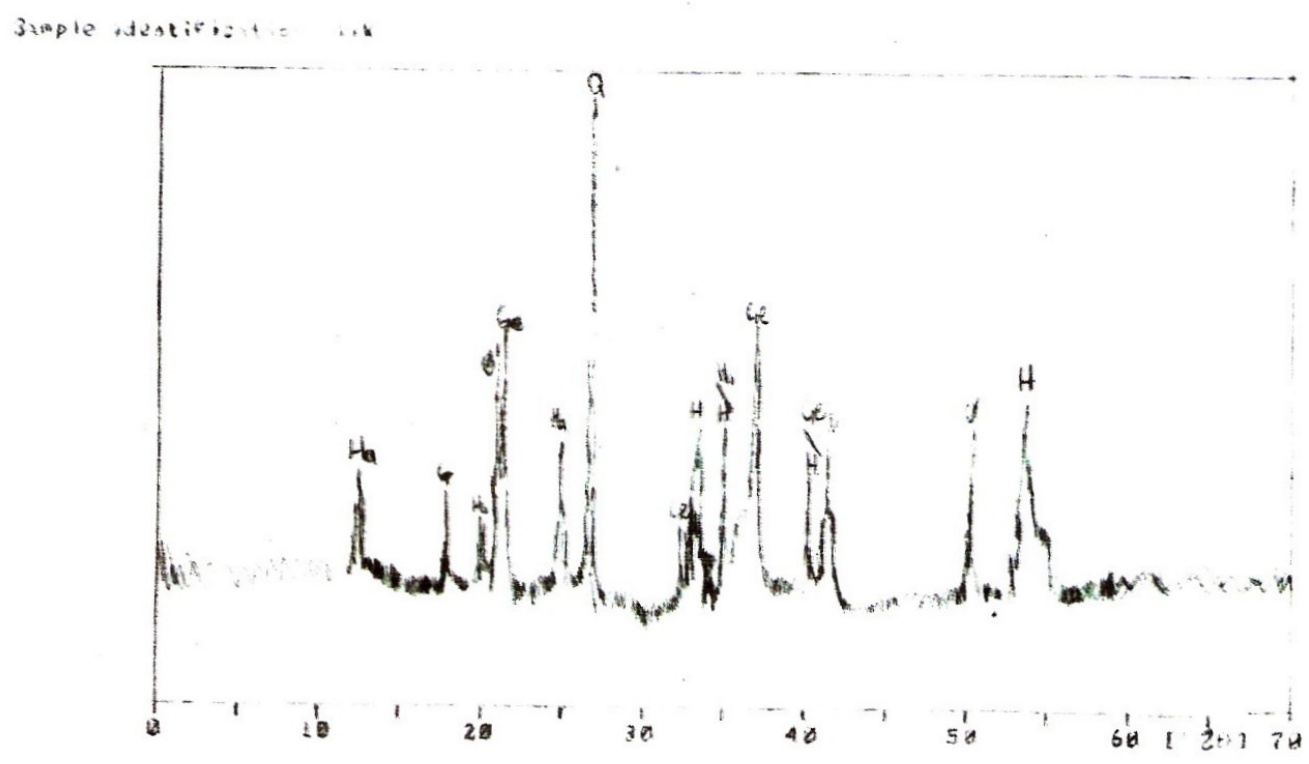

Fig 1: X-Ray Diffractogram of Laterite in lyuku

$\mathrm{Ha}=$ Halloysite,$\quad \mathrm{Ge}=$ Geothite,$\quad \mathrm{H}=$ Haematite,$\quad \mathrm{Q}=$ Quartz, $\mathrm{G}=$ Gibbsite

The results of the chemical assay of the lyuku lateritic iron deposit is as presented in table 1 . The results obtained were as follows: moisture content $(1.01-1.70 \%)$, loss on ignition (L. O. I.), (4.08 - 8.35\%) Iron (iii) oxide (48.2 $59.00 \%)$ aluminum oxide $(12.5-18.00 \%)$ silica $(9.48-$ $30.71 \%)$, magnesium oxide $(2.51-2.60 \%)$ calcium oxide $(0.36-0.41 \%)$. The oxides of chromium, vanadium, manganese, nickel, titanium and phosphorus were present inn trace quantities. The mineralogical studies (fig. 1) revealed the presence of goethite and haematite as the main minerals of iron, gibbsite $\left(\mathrm{Al}_{2} \mathrm{O}_{3} \cdot 3 \mathrm{H}_{2} \mathrm{O}\right)$ as the aluminum mineral, halloysite as the clay mineral present, $\infty$-quartz $\left(\mathrm{SiO}_{2}\right)$ and anatase $\left(\mathrm{tiO}_{2}\right)$ were equally detected. The results obtained for the moisture content did not show any predictable pattern. However, there was a progressive decrease in the values of the loss of ignition. (L O. I.) with depth. This can be attributed to the decrease in the carbonaceous materials with increase in depth as the loss on ignition largely represents the volatile matter constituent of organic origin. It was observed that at certain levels, whereas the values of iron oxide decreased with increasing depth, the value of aluminum progressively decreased with increase in depth, but the values of silica progressively increased with depth. This could be attributed to the fact that while the iron minerals decreased in values the clay mineral content of the deposit increased with depth. The higher value of magnesium oxide compared to calcium oxide must be due to the higher solubility of the latter in solution. The occurrence of goethite and haematite as major products of weathering accompanied by kaolinite and low gibbsite and anatase in Nigeria has been reported by Zeese et al (1994). They observed that the presence or absence of other mineral types usually associated with weathering indicates the differences in the parent rock types or weathering environment. The aluminum mineral, gibbsite though identified, appears to be a minor specie. The aluminum oxide present was predominantly of the clay (halloysite) constituent as the ratio of the percentage of silica and aluminum oxide approximates 1:1 which is common with clay of kaolinite type (Jorge et al 2003). The presence of haematite as part of the iron mineral is consistent with the observed mineralogical pattern already predicted by Schellman (1994). Both goethite and haematite are weathering products of the same rock. This view in further supported by the presence of anatase, a titanium mineral $\left(\mathrm{TiO}_{2}\right)$ which accompanies the iron minerals as weathering products of some rock type. The occurrence of both iron minerals as weathering products has long been reported by mudrinic et al (1969) and the 
conversion of haematite to goethite by weathering has equally been reported, Bedarida et al (1971). The $\infty_{-}$ quartz $\left(\mathrm{SiO}_{2}\right)$ present in the deposit is likely more as constituent of the clay rather than discreet quantz. The ratio of silica to the combined oxides of iron and aluminum confirms the deposit as lateritic in nature as predicted by Fey et al (1977).

\section{CONCLUSION}

The laterite iron ore deposit at lyuku, contain high quantity of iron oxide, low quantity of aluminum oxide and moderate quantity of the clay mineral. The deposits consist essentially of goethite and haematite as iron minerals, and halloysite as the clay mineral. The aluminum mineral gibbsite and titanium mineral anatase were present as minor species.

\section{REFERENCES}

A.S.T.M., 1965; Chemical analysis of metals, sampling and analysis of metals bearing ores. American Society for Testing and Materials. Part 32, Pg. $789-791$.

Allen J. R., 1975; Physical geology, George Allen and Unwin, Pg 24

Bedarida F. and Pedemonte G. M., 1971; Haematite to goethite surface weathering. America Mineral 56:14; $67-71$ (Eng).

Emofurieta W. O. Ndesawe. A. L. and Ogunsaju O., 1995; Secondary geochemical and mineralogical dispersion patterns associated with laterization process in Ile - Ife, SW Nigeria. J Min Geol. $31: 39-57$

Iwu G. O., 1973; Characterization of the lateritic iron ores of Hariwa, Guyana, Trans. Inst. Metal. (Sect. B Appli. Earth Sci) 82, B30 - 2.

J. C. P.D Standards 1980; Mineral powder diffraction file vols. I \& II Pub. Int. Centre for Diffraction Data, Parkland, U.S.A.
Jorge C. M. and Cole, C. A., 2003; Kaolinite properties, structure and influence of metal retention on $\mathrm{PH}$. $\mathrm{J}$ Applied clay science Elsavier publisher 23, Pg. $133-139$.

Levin H. L. (1981); Contemporary Physical Geology. Saunders college publishing, Pg 393

Ludman, A. and Cock. N. K. (1982); Physical Geology. McGraw HillBook Company, Pg 188, 501

Mcketta, J. J and Cunningham W. A., 1977; Encyclopedia of chemistry processing and design. Marcel Dekker Vol. 3 Pg. 57 - 67

Mudrinic C and Junjie S. 1969; Mineralogical composition of bauxite deposits in Vlasenica Arh. Ruderstavo Technol. 7(1) 3 - 7 (Croat). Chemical Abstract 75 (1971) 8424

Onyeobi T. U. S. and Imeokparia E. G., 1994; Quantification of amorphous iron in red tropical soils from south - western Nigeria. J. Agric. Sci. Technol 4(1):31 - 38

Onyeobi T. U. S. and Imeokparia E. G. 1995; Chemical and mineralogical transformation in red tropical soils profiles from south - western Nigeria Afri. J. Agric. Sci. Tech. B7(2):27 - 34

Pei-Yuan C., 1977; Table of Key lines in X-ray powder diffraction patterns of minerals in clays and associated rocks. Published by the Dept. of Natural Resources, Geological Survey, Indiana, U.S.A.

Schellmann W., 1994; Geochemical differentiation in laterite and bauxite formation. Catena 21 (2-3), 131 - 143 Eng.

Young R. S., 1971; Chemical analysis in extractive metallurgy. Charles Griffi, London Pg. 172 - 177

Zeese, R; Schwertmann U; Tietz G. F and Jux U., 1994; Mineralogy and stratigraphy of three deep laterite profiles of the Jos plateau (Central Nigeria). Catena 21(2-3), 195 - 214 (Eng). 
